\title{
UJI EFEK ANALGESIK INFUSA DAUN MENGKUDU (Morinda citrifolia L.) PADA MENCIT JANTAN (Mus musculus)
}

\author{
(ANALGESIC EFFECTS TEST OF NONI LEAVES INFUSE (Morinda citrifolia L.) \\ IN MALE MICE (Mus musculus)
}

\section{ELIS SUWARNI, ERNA CAHYANINGSIH, PUTU ERA SANDHI KUSUMA YUDA*}

\author{
*Akademi Farmasi Saraswati Denpasar, Jalan Kamboja No. 11A, Denpasar, Bali
}

\begin{abstract}
Abstrak: Telah dilakukan uji efek analgesik infusa daun mengkudu (Morinda citrifolia L.) dari famili Rubiaceae pada mencit jantan (Mus musculus) menggunakan metode rangsang panas berupa suhu konstan $55^{\circ} \mathrm{C}$. Pada penelitian ini digunakan hewan coba berupa mencit jantan yang dibagi dalam lima kelompok masing-masing terdiri dari enam ekor. Kelompok I sebagai kontrol positif diberi asetosal $65 \mathrm{mg} / \mathrm{Kg} \mathrm{BB}$, kelompok II sebagai kontrol negatif diberi $0.5 \mathrm{ml}$ aquades, kelompok III, IV dan V sebagai kelompok uji diberi $2.5 \mathrm{ml} / 100 \mathrm{~g}$ BB infusa daun mengkudu dengan konsentrasi masing-masing 5\%, 10\% dan 20\%. Pengamatan dilakukan terhadap waktu reaksi, yaitu selang waktu antara penempatan mencit di atas hot plate dan munculnya respon pertama pada mencit berupa melompat atau menjilat kakinya sebagai reaksi untuk mengurangi nyeri. Data yang diperoleh selanjutnya dianalisis dengan metode statistik (ANOVA). Hasil penelitian menunjukkan bahwa terjadi peningkatan waktu reaksi pada kelompok mencit yang diberi infusa daun mengkudu. Dengan demikian dapat disimpulkan bahwa infusa daun mengkudu memiliki efek analgesik pada mencit jantan (Mus musculus).
\end{abstract}

Kata kunci: Analgesik, infusa daun mengkudu, rangsang panas.

\begin{abstract}
Analgesic Effects Test of Noni Leaves Infuse (Morinda citrifolia L.) of Rubiaceae family in Male Mice (Mus musculus) using heat stimuli such as constant temperature of $55^{\circ} \mathrm{C}$ has been done. This study used laboratory animals such as male mice which were divided into five groups, each consisting of six mices. Group I as positive control was given acetosal $65 \mathrm{mg} / \mathrm{Kg}$ body weight; Group II as negative control was given $0.5 \mathrm{ml}$ of distilled water; group III, IV and V as test groups were given $2.5 \mathrm{ml} / 100 \mathrm{~g}$ body weight of Noni Leaves Infuse with concentration of 5\%,10\% and 20\%, respectively. Observations were made on the reaction time, that is the interval between the placement of mice on a hot plate and the emergence of the first response in mice in the form of jump or lick his feet as a reaction to reduce pain. The data were then analyzed with statistical methods (ANOVA). The results showed that an increase of reaction time in the group of mice were given noni leaves infuse. It can be concluded that noni leaves infuse (Morinda citrifolia L.) has analgesic effects in male mice (Mus musculus).
\end{abstract}

Keywords: Analgesic, noni leaves infuse, heat stimuli.

\section{PENDAHULUAN}

Indonesia telah dikenal akan kekayaan alamnya yang luar biasa. Segala macam hasil tumbuhan yang ada di Indonesia dapat dimanfaatkan untuk kepentingan masyarakat. Di masa lalu, bangsa Indonesia telah menggunakan berbagai ramuan dari daun, akar, buah, kayu dan umbi-umbian untuk mendapatkan kesehatan dan menyembuhkan berbagai penyakit. Selain itu, bahan-bahan alami tersebut juga digunakan untuk perawatan kecantikan secara lengkap. Berbagai ramuan tradisional tersebut sering dikenal sebagai pengobatan herba (Suparnini dan Wulandari, 2014). Hal ini menunjukkan dukungan WHO terhadap penggunaan obat tradisional sebagai salah satu alternatif pengobatan yang lebih dikenal dengan back to nature yang dalam hal tertentu lebih menguntungkan jika dibandingkan pengobatan dengan obat sintetik atau modern (Wasito, 2011).

Obat tradisional yang berasal dari tanaman pada umumnya memiliki efek samping yang lebih rendah tingkat bahayanya dibandingkan obatobatan sintetik, walaupun tidak semua tanaman obat aman untuk dikonsumsi. Kurangnya pengetahuan dan informasi yang memadai mengenai berbagai jenis tumbuhan yang dipakai sebagai ramuan obat-obatan tradisional untuk pengobatan penyakit tertentu dan cara 
pembuatannya menjadi masalah dan kesulitan bagi para peminat obat-obatan tradisional sampai saat ini (Lesiasel, dkk., 2013).

Salah satu jenis tumbuhan yang dikenal memiliki banyak khasiat adalah mengkudu atau sering disebut pace (Morinda citrifolia L.) yang tergolong dalam famili Rubiaceae. Meskipun secara fisik tumbuhan itu berbentuk jelek dan cukup berbau, ternyata ia memiliki khasiat yang sangat beragam (Kandi, 2006).

Tanaman mengkudu termasuk dalam tumbuhan obat yang sudah dimanfaatkan untuk pengobatan tradisional di Indonesia salah satunya sebagai analgesik (Widasari, dkk., 2014). Uji in vitro, in vivo dan uji klinik terhadap buah mengkudu menunjukkan adanya aktivitas antimikroba, antivirus, antifungi, antioksidan, analgesik, antioksidan, antiinflamasi, antelmintik, antiobesitas dan antidislipidemia. Sedangkan daun mengkudu diketahui memiliki aktivitas antimikroba, antioksidan, antiinflamasi, antelmintik, antiobesitas dan antidislipidemia (Assi et al., 2015).

Zat aktif utama dalam daun mengkudu meliputi: terpenoid, ascorbic acid, beta karoten, Iarginine, xeronine, dan proxeronine. (Sitepu dan Josua, 2012 dalam Aryadi, 2014). Buah mengkudu mengandung alkaloid triterpenoid, skopoletin, acubin, alizarin, antraquinon, asam benzoat, asam oleat, asam palmitat, glukosa, eugenol, dan hexanal (Rukmana, 2002 dalam Aryadi, 2014). Beberapa senyawa yang terkandung dalam tanaman mengkudu yang diduga bersifat analgesik antara lain scopoletin, flavonoid, proxeronine dan xeronine (Widasari, dkk., 2014).

Analgesik adalah bahan atau obat yang digunakan untuk menekan atau mengurangi rasa sakit atau nyeri tanpa menyebabkan hilangnya kesadaran atau analgesik adalah senyawa yang dalam dosis terapeutik meringankan atau menekan rasa nyeri, tanpa memiliki kerja anestesi umum. Analgesik terbagi menjadi dua kelompok utama yaitu analgesik opioid dan analgesik non-opioid. Analgesik opioid merupakan kelompok obat yang selain memiliki efek analgesik, juga memiliki efek seperti opium. Analgesik opioid digunakan dalam penatalaksanaan nyeri sedang sampai berat (Pandey, dkk., 2013).

Rasa sakit atau nyeri merupakan pertanda ada bagian tubuh yang bermasalah. Yang merupakan suatu gejala, yang fungsinya adalah melindungi serta memberikan tanda bahaya tentang adanya gangguan-gangguan di dalam tubuh seperti peradangan (rematik, encok), infeksi kuman atau kejang otot (Asteya, 2010).
Penelitian yang dilakukan oleh Lesiasel dkk. (2013) menunjukkan bahwa ekstrak etanol buah mengkudu memiliki efek analgesik pada mencit (Mus musculus). Penelitian ini bertujuan untuk mengetahui apakah infusa daun mengkudu (Morinda citrifolia L.) memiliki efek analgesik pada mencit jantan (Mus musculus). Menurut Farmakope Indonesia Edisi IV (1995), infusa adalah sediaan cair yang dibuat dengan mengekstraksi simplisia nabati dengan air pada suhu $90^{\circ} \mathrm{C}$ selama 15 menit. Metode penyarian yang digunakan dalam penelitian ini adalah metode infusa, karena metode infusa ini merupakan metode yang sederhana, dan menggunakan air sebagai penyarinya. Oleh karena itu dengan metode infusa ini diharapkan zat aktif yang terdapat di dalam daun mengkudu yang diduga memiliki aktivitas analgesik dapat tersari dengan baik.

\section{BAHAN DAN METODE}

Bahan. Bahan tanaman yang digunakan dalam penelitian ini adalah daun mengkudu (Morinda citrifolia L.) yang tumbuh di desa Subagan, Karangasem, Bali, dan telah dideterminasi di Lembaga Ilmu Pengetahuan Indonesia UPT Balai Konservasi Tumbuhan Kebun Raya "EKA KARYA" Bali. Bahan lain yang digunakan sebagai penunjang penelitian ini adalah asetosal sebagai kontrol positif dan aquades sebagai kontrol negatif.

Alat. Alat-alat yang digunakan dalam penelitian ini meliputi : kanul tumpul, stopwatch, timbangan, hot plate, panci infus, kompor listrik, beker gelas, kertas saring, kandang pemeliharaan mencit, batang pengaduk, termometer, kain flannel.

Hewan Percobaan. Pada pengujian ini digunakan hewan percobaan mencit jantan (Mus musculus) sehat berumur \pm 2 bulan pada saat perlakuan uji dengan bobot mencit 20-24 g yang memiliki kondisi fisik sehat dan aktif.

Pembuatan Infusa Daun Mengkudu. Untuk membuat $100 \mathrm{ml}$ infusa daun mengkudu 5\%, 10\% dan 20\%, masing-masing ditimbang serbuk simplisia daun mengkudu sebanyak: $5 \mathrm{~g}, 10 \mathrm{~g}$ dan 20g. Kemudian masing-masing simplisia dimasukkan ke dalam panci infus, dan ditambahkan air sebanyak $100 \mathrm{ml}(+2 \mathrm{x}$ bobot simplisia). Masing-masing panci infus dipanaskan di atas penangas air selama 15 menit terhitung dari suhu pelarut mencapai $90^{\circ} \mathrm{C}$, kemudian disaring. 
Metode. Pada penelitian ini, tiga puluh ekor mencit jantan dikelompokkan secara acak menjadi 5 kelompok, masing-masing kelompok terdiri dari 6 ekor. Sebelum dilakukan pengujian, mencit terlebih dahulu diadaptasi selama 10 hari dan dipuasakan selama 6 jam. Kelompok I sebagai kontrol positif diberi asetosal dengan dosis 65 $\mathrm{mg} / \mathrm{Kg} \mathrm{BB}$; kelompok II sebagai kontrol negatif diberi $0.5 \mathrm{ml}$ aquades; kelompok III, IV dan V sebagai kelompok uji diberi $2.5 \mathrm{ml} / 100 \mathrm{~g}$ BB infusa daun mengkudu dengan konsentrasi masingmasing 5\%,10\%, dan 20\%. Masing-masing sampel diberikan secara oral. Hewan didiamkan selama 15 menit untuk memberikan kesempatan distribusi obat ke dalam tubuh. Selanjutnya dilakukan pengujian dengan menggunakan metode rangsang panas menggunakan alat hot plate dengan suhu konstan $55^{\circ} \mathrm{C}$. Tiap mencit ditaruh di atas hot plate, kemudian dicatat waktu reaksi yang diperlukan. Waktu reaksi adalah selang waktu antara penempatan mencit di atas hot plate dan munculnya respon pertama pada mencit yaitu berupa melompat atau menjilat kakinya sebagai reaksi untuk mengurangi nyeri. Waktu reaksi ini dapat diperpanjang oleh obat-obat analgetik. Perpanjangan waktu reaksi ini selanjutnya dapat dijadikan sebagai ukuran dalam mengevaluasi aktivitas analgetik (Puspitasari dkk., 2003 dalam Turner, 1965; Sirait dkk., 1993). Data yang diperoleh dianalisis dengan metode statistik (One Way ANOVA).

\section{HASIL DAN PEMBAHASAN}

Pada penelitian ini digunakan mencit sebagai hewan percobaan karena keunggulannya, yaitu ukuran badan yang kecil, mudah berkembang biak, harga dan biaya perawatan murah. Selain itu, seringnya mencit digunakan dalam penelitian membuat hewan ini paling dipahami dan dikarakterisasi dengan baik secara anatomi, fisiologi dan genetik.

Pemilihan mencit jantan dilakukan karena pada mencit betina dapat mengalami siklus fluktuasi dari waktu ke waktu karena siklus hormon yang dapat mempengaruhi hasil penelitian.

Sebelum mendapatkan perlakuan, mencit terlebih dahulu diadaptasi selama 10 hari dan dipuasakan makan selama 6 jam sebelum pengujian. Adaptasi terhadap lingkungan bertujuan supaya mencit tidak merasakan asing dan tidak mengalami stress atau depresi yang dapat mempengaruhi hasil pengujian dan interpretasi data (Moore, 2000).

Sebagai kontrol positif pada penelitian ini digunakan asetosal. Asam asetil salisilat atau yang lebih dikenal dengan asetosal atau aspirin merupakan senyawa yang memiliki khasiat sebagai analgesik, antipiretik, dan anti inflamasi pada penggunaan dosis besar. Asetosal termasuk produk over the counter (OTC) yang dapat diperoleh tanpa resep dokter dan telah digunakan secara luas di masyarakat (Sweetman, 2002).

Induksi nyeri secara termik dalam penelitian ini menggunakan suhu konstan yaitu $55^{\circ} \mathrm{C}$, karena suhu kritis rata-rata sebesar $45^{\circ} \mathrm{C}$ saat seseorang mulai merasakan sakit dan reseptor panas mempunyai respon terhadap suhu $30-45^{\circ} \mathrm{C}$, suhu di atas $45^{\circ} \mathrm{C}$ mulai terjadi kerusakan jaringan akibat panas dan sensasinya berubah menjadi nyeri. Jadi, rasa nyeri yang disebabkan oleh panas sangat erat hubungannya dengan kemampuan panas untuk merusak jaringan (Guyton, 1994).

Pada penelitian ini, pengamatan dilakukan terhadap waktu reaksi yang diperlukan. Waktu reaksi adalah selang waktu antara penempatan mencit di atas hot plate dan munculnya respon pertama pada mencit yaitu berupa melompat atau menjilat kakinya sebagai reaksi untuk mengurangi nyeri. Data hasil pengujian dapat dilihat pada tabel 1 .

Tabel 1. Waktu Reaksi pada Mencit Jantan Balb/C (Kelompok Kontrol positif, Kelompok Kontrol negatif dan Kelompok Uji)

\begin{tabular}{c|c|c|c|c|c}
\hline \multirow{2}{*}{ Mencit } & \multicolumn{4}{|c}{ Waktu Reaksi (Detik) } \\
\cline { 2 - 5 } & $\begin{array}{c}\text { Kelompok } \\
\text { Kontrol (+) } \\
\text { (Asetosal) }\end{array}$ & $\begin{array}{c}\text { Kelompok } \\
\text { Kontrol (-) } \\
\text { (Aquades) }\end{array}$ & $\begin{array}{c}\text { Infusa Daun } \\
\text { Mengkudu } \\
\text { Konsentrasi } \\
\mathbf{5 n \%}\end{array}$ & $\begin{array}{c}\text { Knfusa Daun } \\
\text { Mengkudu } \\
\text { Konsentrasi 10\% }\end{array}$ & $\begin{array}{c}\text { Infusa Daun } \\
\text { Mengkudu } \\
\text { Konsentrasi 20\% }\end{array}$ \\
\hline 1 & 18.00 & 5.00 & 10.00 & 12.00 & 19.00 \\
2 & 15.00 & 9.00 & 11.00 & 12.00 & 14.00 \\
3 & 17.00 & 7.00 & 15.00 & 15.00 & 20.00 \\
4 & 10,00 & 7.00 & 10.00 & 17.00 & 12.00 \\
5 & 11.00 & 6.00 & 12.00 & 10.00 & 10.00
\end{tabular}




\begin{tabular}{c|c|c|c|c|c}
6 & 19.00 & 8.00 & 19.00 & 13.00 & $8, .00$ \\
\hline Rata-rata & $\mathbf{1 5 . 0 0} \pm \mathbf{3 . 4 2}$ & $\mathbf{7 . 0 0} \pm \mathbf{1 . 2 9}$ & $\mathbf{1 2 . 8 3} \pm \mathbf{3 . 2 4}$ & $\mathbf{1 3 . 1 7} \pm \mathbf{2 . 2 7}$ & $\mathbf{1 3 . 8 3} \pm \mathbf{4 . 4 1}$ \\
\hline
\end{tabular}

Dari tabel 1. dapat diketahui bahwa kelompok kontrol negatif yang diberi aquades memiliki waktu reaksi rata-rata yang paling rendah yaitu $7.00 \pm 1.29$ detik. Kelompok uji yang diberi infusa daun mengkudu dengan kosentrasi $5 \%$, $10 \%$, dan $20 \%$ menunjukkan peningkatan waktu reaksi rata-rata dibandingkan dengan kelompok kontrol negatif yang diberi aquades, yaitu berturutturut $12.83 \pm 3.24,13.17 \pm 2.27$ dan $13.83 \pm 4.41$ detik. Kelompok kontrol positif yang diberi asetosal menunjukkan waktu reaksi rata-rata yang paling tinggi yaitu $15.00 \pm 3.42$ detik. Hal ini menunjukkan bahwa baik asetosal maupun infus daun mengkudu dapat meningkatkan daya tahan mencit terhadap rasa nyeri yang ditimbulkan oleh rangsang panas dari hot plate.

Data yang diperoleh dari hasil uji efek analgesik infusa daun mengkudu selanjutnya dianalisis dengan metode statistik (One Way ANOVA). Hasil uji statistik dapat dilihat pada tabel 2 dan 3.

\section{Tabel 2. Anova: Aktivitas Analgesik Infusa Daun Mengkudu, Aquades dan Asetosal}

Detik Aktivitas Motorik Mencit

\begin{tabular}{|l|l|l|l|l|l|}
\hline & Sum of Squares & Df & Mean Square & F & Sig. \\
\hline Between Groups & 232.467 & 4 & 58.117 & 5.001 & .004 \\
Within Groups & 290.500 & 25 & 11.620 & & \\
Total & 522.967 & 29 & & & \\
\hline
\end{tabular}

Tabel 2. Menunjukkan adanya perbedaan bermakna antara waktu reaksi pada kelima kelompok mencit, yaitu kelompok uji (infusa daun mengkudu konsentrasi 5\%, $10 \%$ dan 20\%), kelompok kontrol negatif (aquades) dan kelompok kontrol positif (asetosal) dengan nilai $\mathrm{P}=0.004$ $(\mathrm{P}<0.05)$.

Tabel 3. Multiple Comparisons: Aktivitas Analgesik Infusa Daun Mengkudu, Aquades dan Asetosal

Dependent Variable:Waktu Respon Nyeri Mencit

\section{Multiple Comparisons}




\begin{tabular}{|c|c|c|c|c|c|c|c|}
\hline & \multirow[b]{2}{*}{ (I) Kelompok } & \multirow[b]{2}{*}{ (J) Kelompok } & \multirow{2}{*}{$\begin{array}{c}\text { Mean } \\
\text { Difference (I- } \\
\mathrm{J})\end{array}$} & \multirow[b]{2}{*}{ Std. Error } & \multirow[b]{2}{*}{ Sig. } & \multicolumn{2}{|c|}{$95 \%$ Confidence Interval } \\
\hline & & & & & & $\begin{array}{l}\text { Lower } \\
\text { Bound }\end{array}$ & $\begin{array}{l}\text { Upper } \\
\text { Bound }\end{array}$ \\
\hline \multirow[t]{20}{*}{ Tukey HSD } & \multirow[t]{4}{*}{ Kelompok A } & Kelompok B & $8.000^{*}$ & 1.968 & .004 & 2.22 & 13.78 \\
\hline & & Kelompok C & 2.167 & 1.968 & .804 & -3.61 & 7.95 \\
\hline & & Kelompok D & 1.833 & 1.968 & .882 & -3.95 & 7.61 \\
\hline & & Kelompok E & 1.167 & 1.968 & .975 & -4.61 & 6.95 \\
\hline & \multirow[t]{4}{*}{ Kelompok B } & Kelompok A & $-8.000^{*}$ & 1.968 & .004 & -13.78 & -2.22 \\
\hline & & Kelompok C & $-5.833^{*}$ & 1.968 & .047 & -11.61 & -.05 \\
\hline & & Kelompok D & $-6.167^{*}$ & 1.968 & .032 & -11.95 & -.39 \\
\hline & & Kelompok E & $-6.833^{*}$ & 1.968 & .015 & -12.61 & -1.05 \\
\hline & \multirow[t]{4}{*}{ Kelompok C } & Kelompok A & -2.167 & 1.968 & .804 & -7.95 & 3.61 \\
\hline & & Kelompok B & $5.833^{*}$ & 1.968 & .047 & .05 & 11.61 \\
\hline & & Kelompok D & -.333 & 1.968 & 1.000 & -6.11 & 5.45 \\
\hline & & Kelompok E & -1.000 & 1.968 & .986 & -6.78 & 4.78 \\
\hline & \multirow[t]{4}{*}{ Kelompok D } & Kelompok A & -1.833 & 1.968 & .882 & -7.61 & 3.95 \\
\hline & & Kelompok B & $6.167^{*}$ & 1.968 & .032 & .39 & 11.95 \\
\hline & & Kelompok C & .333 & 1.968 & 1.000 & -5.45 & 6.11 \\
\hline & & Kelompok E & -.667 & 1.968 & .997 & -6.45 & 5.11 \\
\hline & \multirow[t]{4}{*}{ Kelompok E } & Kelompok A & -1.167 & 1.968 & .975 & -6.95 & 4.61 \\
\hline & & Kelompok B & $6.833^{*}$ & 1.968 & .015 & 1.05 & 12.61 \\
\hline & & Kelompok C & 1.000 & 1.968 & .986 & -4.78 & 6.78 \\
\hline & & Kelompok D & .667 & 1.968 & .997 & -5.11 & 6.45 \\
\hline
\end{tabular}

Keterangan

Kelompok A : Kelompok kontrol positif (Asetosal)

Kelompok B : Kelompok control negatif (Aquades)

Kelompok C : Kelompok uji (Infusa daun mengkudu konsentrasi 5\%)

Kelompok D : Kelompok uji (Infusa daun mengkudu konsentrasi 10\%)

Kelompok E : Kelompok uji (Infusa daun mengkudu konsentrasi 20\%)

Berdasarkan tabel 3. Dapat diketahui bahwa ada perbedaan bermakna waktu reaksi antara kelompok kontrol positif (asetosal) dengan kelompok kontrol negatif (aquades) dengan nilai $\mathrm{P}=0.004 \quad(\mathrm{P}<0.05)$. Sedangkan antara kelompok kontrol positif (asetosal) dengan ketiga kelompok uji (infusa daun mengkudu 5\%, 10\% dan 20\%) diperoleh nilai $\mathrm{P}$ masing-masing $0.804,0.882$ dan 0.975 ( $\mathrm{P}>0.05)$. Hal ini menunjukkan tidak ada perbedaan bermakna waktu reaksi antara kelompok kontrol positif (asetosal) dengan masing-masing kelompok uji (infus daun mengkudu 5\%,10\% dan $20 \%$ ).

Dari hasil analisis statistik antara kelompok kontrol negatif (aquades) dengan ketiga kelompok uji (infusa daun mengkudu 5\%, 10\% dan 20\%) diperoleh nilai P masing-masing $0.047,0.032$ dan $0.015(\mathrm{P}<0.05)$. Hal ini menunjukkan bahwa ada perbedaan bermakna waktu reaksi antara kelompok kontrol negatif (aquades) dengan masing-masing kelompok uji tersebut. Sedangkan antara sesama kelompok uji (infus daun mengkudu $5 \%, 10 \%$ dan $20 \%$ ) masing-masing menunjukkan nilai $\mathrm{P}>0,05$. Hal ini menunjukkan bahwa tidak ada perbedaan yang bermakna diantara masingmasing kelompok uji tersebut.

Berdasarkan hasil analisis tersebut di atas, maka dapat diketahui bahwa infusa daun mengkudu 5\%, $10 \%$ dan $20 \%$ memiliki aktivitas analgesik.

Salah satu senyawa yang terkandung dalam daun mengkudu adalah proxeronine (Sitepu dan Josua, 2012 dalam Aryadi, 2014). Menurut Widasari dkk. (2014), Proxeronine merupakan senyawa yang diduga bersifat analgesik. Berdasarkan hal tersebut maka diduga bahwa aktivitas analgesik infus daun mengkudu disebabkan oleh kandungan senyawa Proxeronine tersebut.

\section{SIMPULAN}

Berdasarkan hasil penelitian dapat disimpulkan bahwa infus daun mengkudu (Morinda citrifolia L.) memiliki efek analgesik pada mencit jantan (Mus musculus). 


\section{DAFTAR PUSTAKA}

Aryadi, I. G. A. I. P., 2014, Pengaruh Ekstrakdaun Mengkudu (Morinda citrifolia L.) Terhadap Pertumbuhan Staphylococcus aureus Sebagai Penyebab Abses Periodontal Secara In Vitro, Skripsi, Fakultas Kedokteran Gigi, Universitas Mahasaraswati Denpasar, Denpasar.

Assi, R. A., Darwis, Y., Abdulbaqi, I. M., Khan, A. A., Vuanghao L., Laghari, M. H., 2015, Morinda citrifolia (Noni) : A comprehensive review on its industrial uses, pharmacological activities, and clinical trials, Arabian Journal of Chemistry, $\mathrm{xxx}$.

Asteya, D. M., 2010, Sintesis Asam-2 (2'Klorobenzoiloksi) Benzoat dan Uji Aktivitas Analgesik Pada Mencit (Mus musculus), Skripsi, Fakultas Farmasi, Universitas Airlangga, Surabaya.

Depkes RI, 1995, Farmakope Indonesia, Edisi IV, Departemen Kesehatan Republik Indonesia.

Guyton, A.C., 1994, Buku Ajar Fisiologi Kedokteran, Penerjemah: Tengadi, K.A., Jakarta: EGC.

Kandi, 2006, Mengkudu yang Multiguna, CV. Jasa Grafika Indonesia, Jakarta.

Lesiasel, R.N., Awaloe, H., Posangi, J. 2013, Uji Efek Analgesik Ekstrak Etanol Buah Mengkudu (Morinda Citrifolia L.) pada Mencit (Mus musculus), Jurnal e-Biomedik (eBM), 1(1): 765-770 diakses pada 15 Januari 2015,

<http://ejournal.unsrat.ac.id/index.php/ebiom edik/article/view/3633/3160>.
Lucia, E.W. 2013, Eksperimen Farmakologik Orientasi Preklinik, Surabaya.

Moore, D. 2000. Laboratory Animal Medicine and Science Series II. University of Washington Health Science Centre. Washingtong. p 1-23.

Pandey, P. V., Bodhi, W., Yudistira, A. 2013, Uji Efek Analgesik Ekstrak Rumput Teki (Cyperus rotundus L.) pada Tikus Putih Jantan Galur Wistar (Rattus novergicus), Pharmacon Jurnal Ilmiah FarmasiUNSRAT, 2(02): 2302-2493 diakses pada 20 Januari 2015 , http://ejournal.unsrat.ac.id/index.php/pharma con/article/viewFile/1579/1271.

Puspitasari, H., Listyawati, S., Widiyayani, T., 2003, Aktivitas Analgetik Ekstrak Umbi Teki (Cyperus rotundus L.) pada Mencit Putih (Mus Musculus L.) Jantan, Biofarmasi 1 (2): 50-57.

Suparmini, I. dan Wulandari, A. 2014, Herbal Nusantara 1001 Ramuan Tradisional Asli Indonesia, Edisi 1, Rapha Publishing, Yogjakarta.

Sweetman, C.S (editor). 2002, Martindale The Complete Drug Reference, 33th edition, Pharmaceutical Press, London, UK, p. 14-18.

Wasito, H. 2011, Obat Tradisional Kekayaan Indonesia, Graha Ilmu, Yogyakarta.

Widasari, F., Bakhiriansyah, M., Istiana. 2014, Studi Interaksi Farmakodinamik Efek Analgetik Kombinasi Perasan Buah Mengkudu (Morinda citrifolia L.) dengan Parasetamol, Berkala Kedokteran, 10(1): 3140 diakses pada tanggal 10 Februari 2015, $<$ http://ejournal.unlam.ac.id/index.php/bk/arti cle/download/811/758>. 